\title{
Editorial
}

\section{Que Psicologia Escolar e Educacional queremos?}

Constata-se, desde o início da Psicologia brasileira, a necessidade de caracterizar a atuação do Psicólogo Escolar. A UNESCO foi pioneira, em 1948, ao sistematizar informações acerca da formação e atuação do psicólogo escolar em diferentes países. Desde esta época, registra-se, pelas publicações acerca desta temática, a preocupação com a área, no sentido de não somente garantir referências de atuação aos profissionais, mas também e, principalmente, fazê-las em consonância com as regulamentações profissionais e legais atreladas a políticas públicas.

É sabido, e ratificado pela formação ocorrida nos cursos de Psicologia, que a Psicologia Escolar e Educacional é um dos setores da Psicologia voltado para a atuação e investigação em contextos educacionais, considerando sua interface com áreas afins. O processo de ensino e aprendizagem, o desenvolvimento humano, as políticas públicas em educação, a gestão psicoeducacional, a avaliação psicológica e educacional e a formação continuada de professores, são algumas das temáticas de estudo, pesquisa e atuação profissional.

Considerando a necessidade de congregar esforços de estudiosos e profissionais da área, a fim de conquistar a inserção do Psicólogo Escolar nos serviços e instituições educacionais, a Associação Brasileira de Psicologia Escolar e Educacional (ABRAPEE), desde a sua fundação, tem envidado esforços na direção de efetivar tal aspiração. A criação da revista Psicologia Escolar e Educacional como um meio tanto de divulgação e comunicação dos avanços científicos e profissionais do setor, quanto de registro histórico da própria Psicologia Escolar e Educacional, tem cumprido seu papel de interlocutora entre profissionais e pesquisadores da Psicologia brasileira e estrangeira. Estão registradas na revista, em seus 10 anos de publicação, as mudanças ocorridas na formação e atuação profissional do psicólogo escolar em função das características e necessidades sócio-econômicas e educacionais e o momento histórico-cultural brasileiro, pelas pesquisas, resenhas e experiências exitosas publicadas.

Ao lado disso, cabe destacar também que a Psicologia Escolar e Educacional ao ser publicada em acesso aberto no Portal de Periódicos Eletrônicos de Psicologia - PePsic, passou a ter maior visibilidade. Isto gerou aumento do número de artigos submetidos em âmbito nacional e estrangeiro, além de ter o terceiro maior índice de impacto dentre as revistas disponíveis no PePsic, de acordo com os dados bibliométricos gerados no portal para o período dos últimos três anos.

Destaque cabe também, nesta trajetória percorrida pela Psicologia Escolar e Educacional, para os Congressos Nacionais bianuais organizados pela ABRAPEE. Neste último, realizado em abril passado em São João DelRei, a presença de mais de 1600 congressistas permite-nos inferir a dimensão deste setor da Psicologia. A avaliação do evento, feita por aproximadamente $20 \%$ destes participantes, indica que este é tido como uma oportunidade de interação relevante entre profissionais que atuam em distintos setores. Isto se deu pela diversidade de temas, atividades e oportunidades para encontros, trocas e estabelecimento de parcerias para ações futuras na área.

A despeito dos avanços e do compromisso da ABRAPEE enquanto entidade representativa da Psicologia Escolar e Educacional e do próprio setor que vem agregando, sem dúvida, muitos profissionais, pesquisadores e estudantes, há de se conquistar a representatividade profissional do Psicológo escolar como membro de equipes atuantes em diferentes contextos educacionais. Esta é a Psicologia Escolar que queremos: atuante e comprometida com o momento sócio-histórico e cultural do Brasil. 
Neste sentido, foi definido em assembléia da ABRAPEE ocorrida no VIII Congresso Nacional que a meta da entidade é, por um lado, contribuir para a aprovação de um Projeto de Lei visando a criação de políticas públicas voltadas para a atuação dos Psicólogos Escolares. Por outro, definir referências para a atuação profissional comprometida com a sociedade brasileira, contribuindo assim, tanto na formação quanto na atuação dos Psicólogos Escolares. Tais ações contam com a parceria do Sistema Conselhos de Psicologia.

Organizar Representações da ABRAPEE, participar de projetos de investigação e atuação organizados em rede que envolva equipes multidiciplinares, em diferentes regiões brasileiras e com variados focos de atuação, são alguns caminhos possíveis para a Psicologia Escolar que almejamos. Que possamos avançar nesta direção em 2007.

Maria Cristina Rodrigues Azevedo Joly

Editora 